\title{
Problems of competitiveness of industries in ensuring the economic security of Russia
}

\author{
Angela Mottaeva ${ }^{1,2}$ and Ludmila Kopteva ${ }^{3, *}$ \\ ${ }^{1}$ Moscow State University of Civil Engineering, 26, Yaroslavskoye Shosse, 109377, Moscow, Russia \\ ${ }^{2}$ Moscow Region State University, 10A, Radio str., 105005, Moscow, Russia \\ ${ }^{3}$ Saint Petersburg State University of Aerospace Instrumentation, 190000, 67, Bolshaya Morskaia str., \\ Saint-Petersburg, Russia
}

\begin{abstract}
The dynamics of the development of the domestic industrial complex shows significant changes in the organization and management of enterprises in recent years. Undoubtedly, global changes in industrial technologies in developed countries have had a significant impact, taking into account digital transformation, intelligent automation and artificial intelligence. In the present conditions, the Russian industrial complex faces a difficult task-to find the necessary resources to improve its own industrial production and thus maintain the ability to compete with foreign manufacturers. The resolution of this issue is complicated by the weakening Russian economy crisis and the growing sanctions pressure from Western partners against the background of a reduced to a minimum investment inflow. The imposed sanctions packages against the Russian economy not only hinder foreign investors, but also act as obstacles to the supply of modern technologies and high-tech industrial equipment to our country, as well as reduce opportunities for organizing cooperation between foreign and domestic developers. In fact, the goals of such sanctions are considered to be the maximum isolation of Russia's industrial and economic systems for the gradual weakening of our country's economy.
\end{abstract}

\section{Introduction}

The competitiveness is a rather multidimensional category of economics. Therefore, as for the countries, their competitiveness is defined by the ability of the industry to be updated, pass to work with new, perfect technologies. As all enterprises work in the conditions of a certain market pressure, they should decide how to get advantages in opposition with rather strong companies which are present at the world market. The enterprise, seeking for the development, tries to benefit from the fact that the strong companies from the country work at the market, and consumers impose increased requirements to the products quality.

At this stage of the economy development the competition at world level amplifies. At the same time it leads to the fact, that the role of the state increases and amplifies. It is

*Corresponding author: lusis63@mail.ru 
especially important in the situation when our society becomes the information one, and the role of innovations raises. The localized processes are applied to forming and maintenance of competitive advantage. The competitiveness is based not only on technical achievements, but also on the national priorities, cultural and historical values as well as the general development of economy, the enterprises representing it. The structure of the countries competitiveness significantly differs. The reason is that any country cannot be in the lead absolutely in all the fields of activity or even in most of them.

Economic security assumes, that the national economy is protected from threats of internal character and coming from the outside reliably.

If the country, applying various means, ensures the economic security, it has an opportunity to keep the independence, as well as to develop in stable conditions. Society has all the opportunities for ensuring the activity.

It can be explained with the fact that the economy is important not only for the state. It provides activity of the most different state and public institutes, allows citizens to live adequately. It means that before using the term "national security", it is necessary to how much the national economy is viable, what reaction on the threats both within the country and coming from the outside will be. It means, that for the country it is vital to ensure national security [1].

It is necessary to define the problem, to define the real-life threats. It is not less important to offer some methods which will allow to reflect possible threats. Economic security does not exist independently. It on an equal basis with defence capability, protection of ecology, social stability is the integral components of the state security. Economic security is considered in most cases one of the most significant economic characteristics of the economic system. Economic security characterizes how the economy is capable to support acceptable living conditions for the citizens, to provide the branches of economy with resources. Besides, the economic security allows the state to fulfil the national interests fully [2].

If to speak about economic security, the limit of safety is already overcome. Here the main problem is that the solution of essential problems of safety begins only after overcoming some threshold values.

\section{Materials and methods}

The methodological basis of the research was made by the methods and receptions of the statistical analysis, correlation and regression analysis and extrapolation of results.

Some matters of the competitiveness of industries special attention were considered by such authors as A.V. Bogayeva, S.L. Vasilyev, A.A. Porokhovsky, M. Porter, M.V. Svirina, A.S. Seryogina, A.M. Hosev, S.S. Chebotaryov and others.

If we compare the production sphere of Russia and that in the develped countries, the conclusions will be not in the Russia's advantage. The majority of the technologies are based on the essential expenses of materials, work of personnel and energy. It leads to overestimate of the prices in comparison with the analogs from other countries. It is hardly possible to compete on equal terms to other producers in such situation [3].

According to some authors $[4,5,6]$ the need of technological rearmament of the Russian industry, saturation, its high-performance systems of machines and technologies, the latest materials which embody the latest developments of the equipment and science, implementation of digital technologies acts for the achievement of positive results.

Figure 1 presents the analysis of trends of the development of industrial production of world powers in the index of industrial production where at each country it has an 
ambiguous trend both growth, and recession is shown. The above-stated data show that this indicator grew in Russia from 2015 to 2018, but since 2018 till now we see its decrease [7].

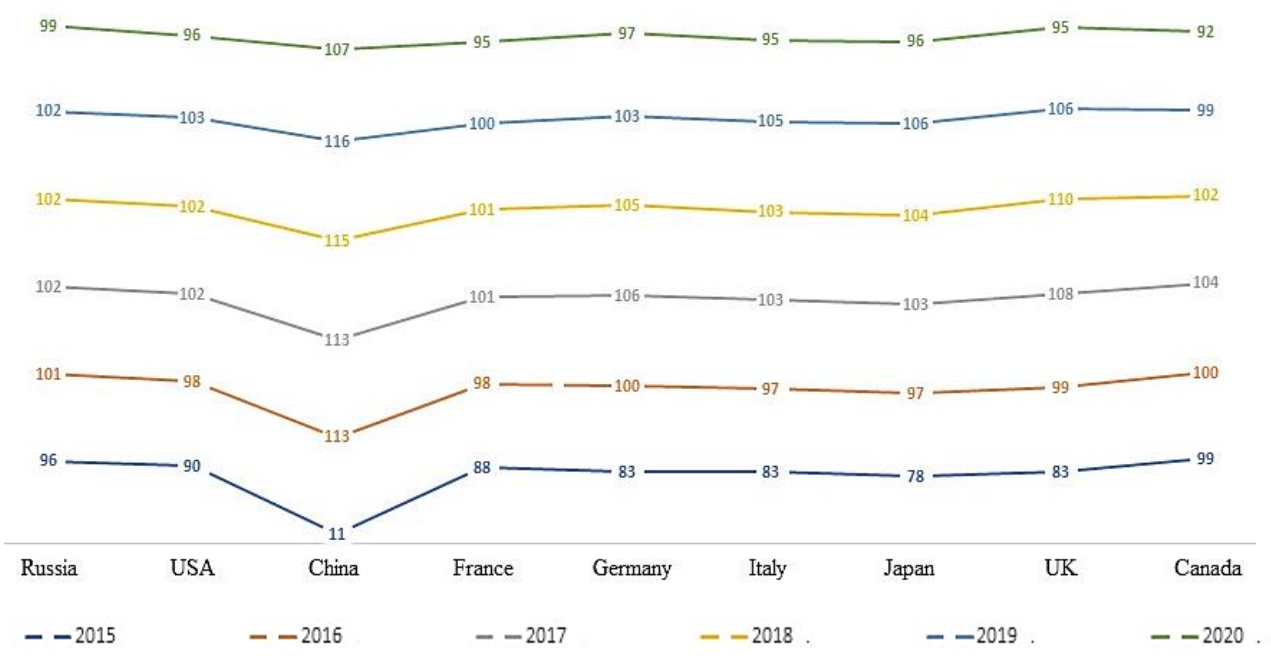

Fig. 1. Dynamics of the index of industrial production of the countries of the world for 2015-2020 (\%, as the percentage to previous year).

Experts considered how the branches of the Russian economy are competitive on internal and external markets and have come to the following conclusions. The enterprises of ferrous metallurgy can compete to the western enterprises on equal terms. Strong competitive positions are taken by the enterprises melting the non-ferrous metals generating the electric power, which are engaged in petroleum refining, gas, the wood. The same group has included the enterprises of defence industry representing communication services.

Mediocre competitive position is peculiar to the enterprises of chemical industry, automobile, civil shipbuilding. Machine-building enterprise and instrument-making complexes cannot compete on equal terms. The weak competitive position is peculiar to civil aircraft construction, production of an electronic equipment, the textile industry.

The Russian enterprises cannot compete on equal terms because many enterprises work on the equipment, outdated both morally, and physically. In the machine-building sector the equipment made 20 and more than years ago is used. It concerns a quarter of all fund. In general business assets of the enterprises are worn-out for $60 \%$. Behind this threshold the equipment needs to be taken out of service. The threat that productive forces of Russia will be destroyed completely amplifies.

Statistical data for the II quarter of 2020 show that the industry of Russia is in crisis. Falling of production has reached 8.5\%. GDP decreased in the same time interval. In 2019 the industrial output increased, but in the I quarter of 2020 the decrease in the index of industrial production by 0.8 items was recorded. It made up $1.5 \%$. The analysis of data for the I half-year of 2020 shows, that the rates of production of manufactured goods were reduced. But the decrease affected not all the industries. For example, the processing productions could bring the gain of production to $3.8 \%$ in annual terms even in the conditions of the lockdown because of the coronavirus pandemic. GDP for the same time grew by $1.8 \%$.

The indexes of the industrial production and physical volume of gross domestic product in Russia in 2014-2020 are presented on figure 2. 


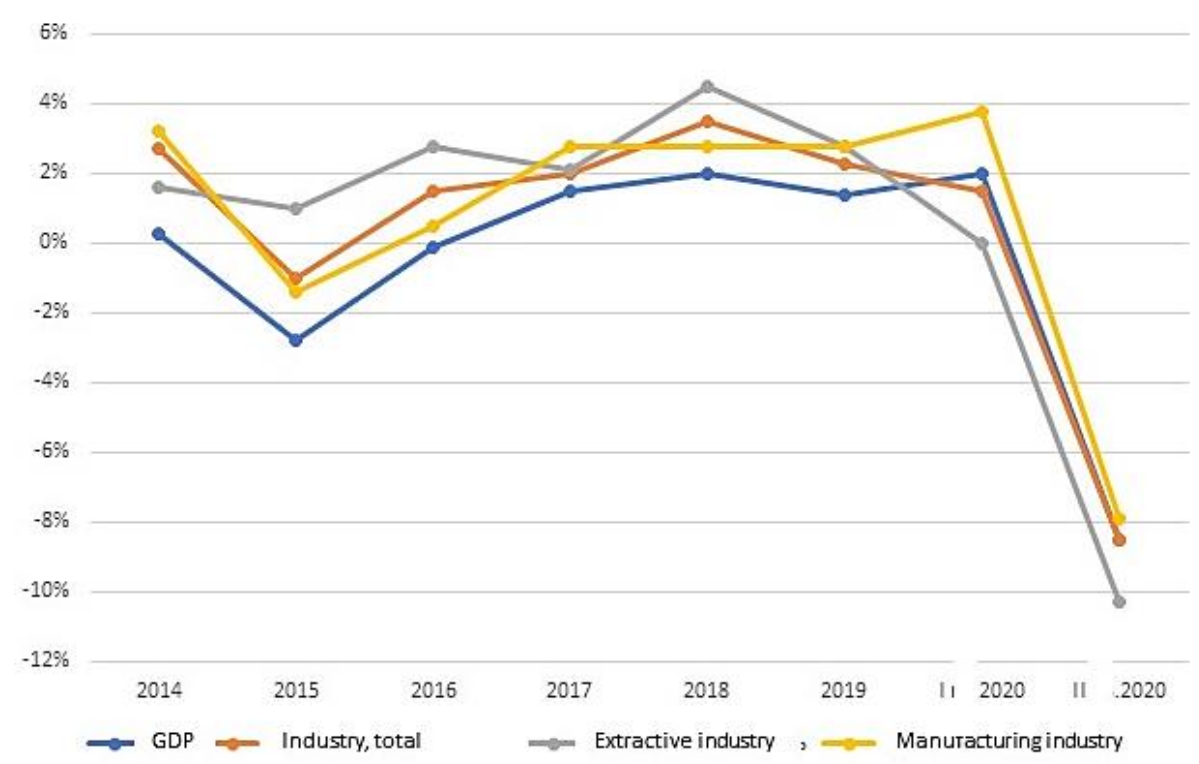

Fig. 2. Indexes of the industrial production and physical volume of gross domestic product in Russia, 2014-2020.

But the negative dynamics is recorded in the II quarter 2020. The information provided by Rosstat demonstrates that the outputs have decreased by $8.5 \%$, GDP decreased the same way. Crisis has affected the extractive industry. Here decrease was $10.3 \%$. Decrease was in manufacturing industry at the level of $7.9 \%$. The reasons which have led to production decrease include:

- the restrictions imposed in connection with observance of the transaction of OPEK+;

- the restrictions introduced with distribution of a pandemic of a coronavirus. According to the order of the government of the enterprise, not belonging to life-supporting, have been obliged to transfer employees whenever possible to a remote operating mode;

- general decline in demand for oil and gas.

The indexes of the industrial production from 2011 till the expected 2030 are shown in Table 1.

Table 1. Indexes of the industrial production in 2011-2030, \%.

\begin{tabular}{|c|c|c|c|c|c|c|c|c|c|c|c|c|c|c|}
\hline & \multirow{4}{*}{$\begin{array}{r}2011 \\
\text { repor }\end{array}$} & \multirow{4}{*}{$\begin{array}{c}2012 \\
\text { report }\end{array}$} & \multicolumn{12}{|c|}{ Forecast } \\
\hline & & & \multicolumn{2}{|c|}{$2015 / 2011$} & \multicolumn{3}{|c|}{$2020 / 2011$} & \multicolumn{3}{|c|}{ 2025/2011 } & \multicolumn{4}{|c|}{$2030 / 2011$} \\
\hline & & & \multicolumn{12}{|c|}{ variants } \\
\hline & & & 1 & 3 & 1 & 2 & 3 & 1 & 2 & 3 & 1 & & 2 & 3 \\
\hline Industry - total & 104.7 & 102.6 & 113.1114 .4 & 116.2 & 129.2 & 2134.9 & 149.4 & 149. & 4156.7 & 182 & 7162 & & 80.82 & 214.9 \\
\hline Mining & 101.9 & 101.1 & 102.3102 .5 & 103.4 & 106.1 & 106.5 & 109.6 & 108.8 & 8109.8 & 114 & 7110 & & 12.51 & 119.5 \\
\hline $\begin{array}{l}\text { Processing } \\
\text { productions }\end{array}$ & 106.5 & 104.1 & 121. & 123.1 & 141. & 149. & 169.1 & 162 & 180.6 & 216 & 187 & & 15 & 262.5 \\
\hline $\begin{array}{l}\text { Production and } \\
\text { power } \\
\text { distribution, } \\
\text { gas and water }\end{array}$ & 100.1 & 101.2 & 105.0105 .2 & 107.9 & 114.4 & 115.6 & 125.7 & 123. & 9124.9 & 140 & 4132 & & $33.6 \mid 1$ & 151.0 \\
\hline
\end{tabular}

Source: "Forecast of long-term social and economic development of the Russian Federation until 2030" (developed by the Ministry of Economic Development of the Russian Federation): http://www.consultant.ru/document. 
The pent-up demand factor became one of the reasons of the improvement of production dynamics. The deficiency in the market which was actively overcome after lifting of restrictions was formed for many types of machine-building products during the lockdown. The agricultural mechanical engineering demonstrated one of the best results among the machine-building subsectors due to the steady demand from the agrarian sector. Only in some machine-building sectors the situation has continued to worsen in the second half of year, including because of surplus in the market of freight cars deep recession is noted in railway mechanical engineering.

\section{Results}

The potential and inertial economic security of the domestic industry is influenced by internal calls and threats, including deterioration and deformation of its structure, reduction of the potential of the production and technological device of the industry and the decrease in the investment-and-innovative activity of the industrial enterprises.

Let us note that the current situation in the world, which is connected with the distribution of the COVID-2019 pandemic, can result in serious damage to all economy of Russia and mechanical engineering including. From this position the assembly enterprises making foreign accessories and materials products are the most vulnerable. Moreover, devaluation of rouble and falling of the oil prices can lead to the decrease in investment activity of the enterprises and to a delay of the made earlier investment decisions. First of all, decrease in demand can happen from the most solvent and wealthy clients (oil holdings), which already begin to reduce the investment plans $[9,10]$.

Despite that the experts believe that positive dynamics of machine-building production will be restored in 2021, and growth will be about $2 \%$. Following the results of the first half of the year 2020 the cumulative release of the industrial production has kept positive dynamics only in the less developed raw $(+22.4 \%)$ and agrarian $(+4.7 \%)$ regions, including the Amur region $(+28.3 \%)$, Chukotka Autonomous Okrug $(+2.3 \%)$ and the Magadan region $(+24.4 \%)$, which became leaders in volume of the shipped self-produced goods (Table 2$)$ [11].

Table 2. The gain of industrial production, \% (January-June, 2020 by January-June, 2019).

\begin{tabular}{|c|l|c|c|c|c|c|}
\hline Group & Type & Total & Processing & Extracting & $\begin{array}{c}\text { Gas, } \\
\text { electric } \\
\text { power }\end{array}$ & $\begin{array}{c}\text { Water } \\
\text { supply and } \\
\text { sanitation }\end{array}$ \\
\hline \multirow{2}{*}{ Advanced } & $\begin{array}{l}\text { Financial-and- } \\
\text { economic } \\
\text { centers }\end{array}$ & -7.8 & -0.6 & -45.4 & 1.0 & -1.9 \\
\cline { 2 - 7 } & $\begin{array}{l}\text { Raw export- } \\
\text { oriented }\end{array}$ & -25.1 & -18.1 & -27.7 & 1.0 & 29.5 \\
\hline & $\begin{array}{l}\text { With } \\
\text { diversified } \\
\text { economy }\end{array}$ & -10.3 & -7.4 & -28.8 & 0.9 & -5.6 \\
\hline $\begin{array}{l}\text { With the } \\
\text { emphasis on } \\
\text { manufacturing } \\
\text { industry thed }\end{array}$ & -5.2 & -2.5 & -21.7 & 1.0 & -2.2 \\
\cline { 2 - 7 } & $\begin{array}{l}\text { With the } \\
\text { emphasis on } \\
\text { the extractive } \\
\text { industry }\end{array}$ & -5.7 & 4.9 & -26.4 & 1.1 & 32.7 \\
\hline Moderately & Industrial- & -2.5 & -1.0 & -20.4 & 1.0 & 12.8 \\
\hline
\end{tabular}




\begin{tabular}{|l|l|c|c|c|c|c|}
\hline developed & and-agrarian & & & & & \\
\cline { 2 - 7 } & $\begin{array}{l}\text { Agrarian-and- } \\
\text { industrial }\end{array}$ & -3.8 & -1.7 & -22.3 & 1.0 & 1.6 \\
\hline \multirow{2}{*}{$\begin{array}{l}\text { The least } \\
\text { developed }\end{array}$} & agrarian & 4.6 & 7.1 & -15.1 & 1.1 & -7.6 \\
\cline { 2 - 7 } & raw & 22.3 & 13.8 & 45.1 & 1.1 & 4.5 \\
\hline
\end{tabular}

Source: Official site of Federal State Statistics Service [Digital resource] https://www.gks.ru (Access Mode 20.01.2021).

The crisis has most affected the regions gaining income from the raw materials export. Their production cutback reached $25.1 \%$. The decrease in the outputs has also affected the regions with the diversified economy. Here reduction was $10.3 \%$. In regions with the developed financial sector and economy reduction has reached $7.8 \%$. The economy of the Nenets Autonomous Okrug has considerably suffered. The reduction was $38 \%$. The reduction in Khanty-Mansi Autonomous district was 30.8\%, the reduction in the Komi Republic was $21.6 \%$. In Moscow the production of manufactured goods was $10.6 \%$ less, in St. Petersburg $11.8 \%$ less. The total negative dynamics regarding the release of manufactured goods in the first half-year in 2020 was recorded in 50 subjects of our country. The positive dynamics was only recorded in 35 subjects. In fact, the manufacturing industry in separate subjects with developed financial-and-economic by sectors of economy did not suffered [12].

At the same time the industries occupied with crude production, coal and gas developed. The Russian raw materials are actively bought up by foreign partners. Aggravation of the problem of ensuring economic security of the industry of Russia is observed in the conditions of globalization of economy and becoming tougher the sanctions by the West implemented for our country.

The problems of weak competitiveness of the industrial enterprises of Russia are connected first of all with lag on growth rates and labour productivity level as concentration of investment and production activity is observed in the industries with the low and average technological way using insufficiently qualified labour. Especially it is visible if to compare among themselves the separate equal foreign and Russian industrial enterprises on volumes of turnover. Low dynamics of technological innovations in the Russian industry and as result, reduction of level of competitiveness of the made goods causes low profitability of the industrial enterprises, control of growth of wage fund, provokes lobbying of unjustified economically protective measures both on federal, and at the regional level $[13,14,15]$.

Ensuring economic security of Russia requires introduction of the mechanism of the state stimulation of forming and introduction of models of technological processes and the new equipment [16]. The lack of the similar mechanism of Russia leads to aggravation of problems in the industry.

Figure 3 demonstrates the main problems complicating functioning of domestic industries at the present stage. 


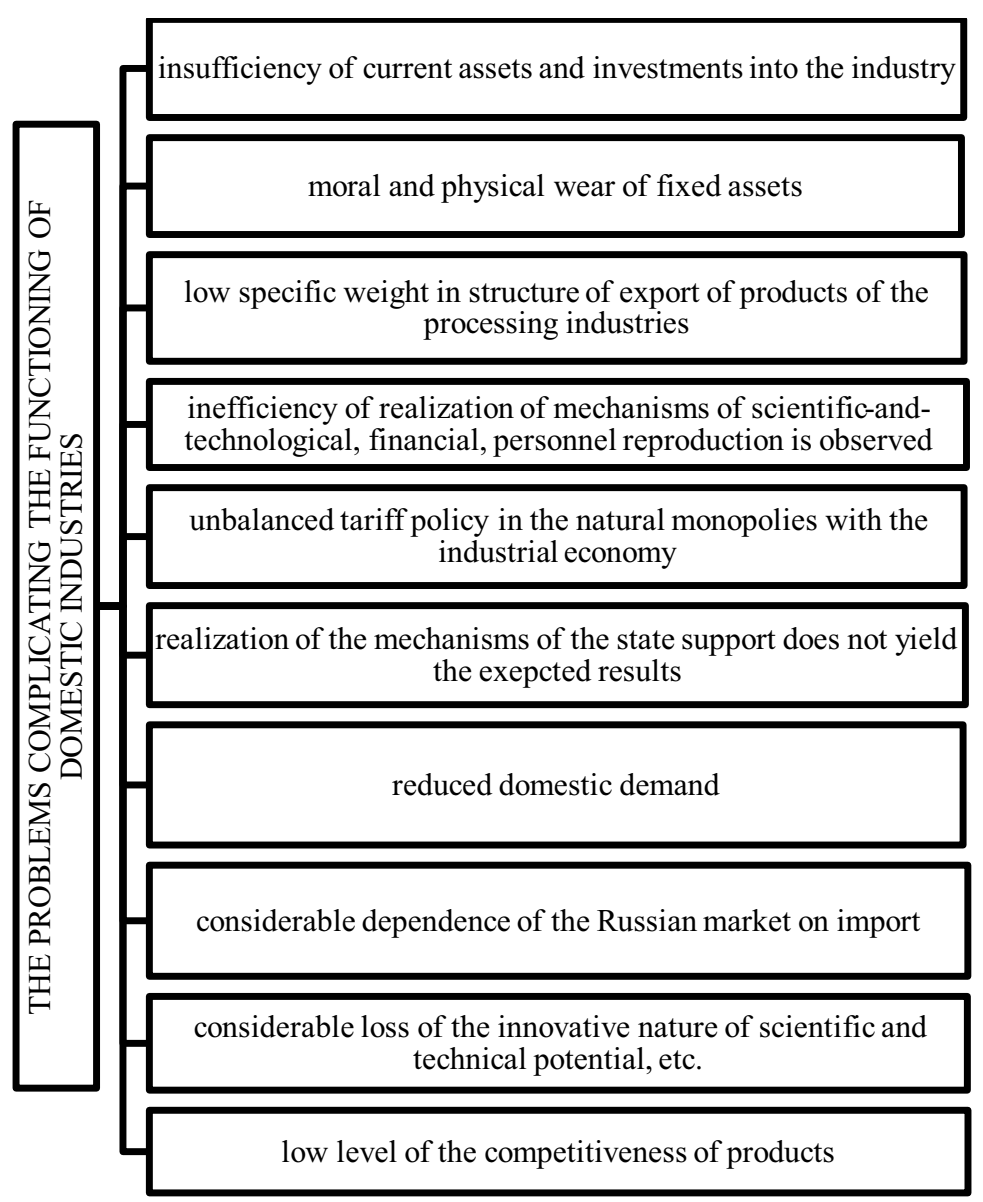

Fig. 3. Main problems of the competitiveness of industries of Russia at the present stage.

Some authors [17-19] considers that "for the purpose of ensuring economic security of the industry introduction of the mechanism of the state stimulation of introduction and creation of samples of the new equipment and technological processes is necessary. The lack of such mechanism of our state leads to the deterioration in problems of functioning of the sphere of the industry".

\section{Conclusions}

The research proves that practically all the industries of the Russian Federation experience difficulties in the financial position of the enterprises which is caused by the decline in the demand for domestic production. The increased prices of industrial output of natural monopolies. Within the modern situation in the economy. Structural threats and disproportions in the development of the scientific and technical sphere and the industry as well as ensuring economic security can increase if certain measures are not taken in time.

The increase in the level of competitiveness of industrial output of Russia should be the key problem of development of domestic industrial production. So activization of investment activities and transfer of the domestic industry to the innovative system of the development is necessary. 
According to the authors. The unevenness of the development of national farms defines the instability of world economy in general. From this point of view restructuring of national economies in the direction of development of the so-called "strategic industries". To which productions of the sphere of life support belong. Is one of the most significant consequences of influence of the COVID-19 pandemic.

In Russia the competition between the enterprises also becomes tougher. "Not price" forms of the competition are involved more often. In this situation to modernize the capacities successfully. Is to introduce an essentially new system of economic security and it will be promoted entering of amendments into standard acts.

Thus. It would be desirable to allocate the main problem for many Russian enterprises of industries. That is the use of outdated technologies and it is necessary to modernize all the spheres and activities in the industrial production for this problem elimination. The products of the domestic industrial enterprises should be competitive. But modern technologies. Change of production processes and estimated goods are necessary for this purpose.

But despite all the problems. The industry of the Russian Federation seeks to reach the high level of the economic development in the world. But. As the analysis of current state of economy shows. Nowadays the undertaken reforms do not solve the problem of the industrial sector and become the reason of a bigger decrease in the rates of its production.

\section{References}

1. T.A. Makarenya et al., Journal of Economic Regulation (Matters of the economy regulation) 3, 36-46 (2019)

2. A.H. Baziyev, Young scientist 48(182), 229-232 (2017)

3. M.V. Svirina, World economy: security concerns 1, 34-36 (2019)

4. A.V. Chernoivanenko, L.V. Shabalin, Modern world economy: calls and reality: materials III of the International scientific and practical DONNTU conference, 180186 (2020)

5. McKinsey: how to save $\$ 370$ billion a year in mining due to digital technologies, https://www.forbes.ru/biznes/340559-mckinsey-kak-cifrovye-tehnologii-snizyat-na-17rashody-v-gornodobyche

6. O.T. Sattorkulov, K.U. Rakhmatov, Young scientist 2(82), 318-321 (2017)

7. Yu.S. Polozhentseva, M.G. Klevtsova. Bulletin of the University 2, 71-79 (2021)

8. A. Akhmetov, Young scientist 14(118), 6-9 (2018)

9. E. Eliseeva, A. Mottaeva, E3S Web Conf., 244, 10028 (2021) DOI: https://doi.org/10.1051/e3sconf/202124410028

10. E. Ganebnykh et al., MATEC Web Conf. 170, 01044 (2018) DOI: https://doi.org/10.1051/matecconf/201817001044

11. S.S. Shishulin, World of new economy 10(4), 135-141 (2018)

12. Official site of Federal State Statistics Service, https://www.gks.ru

13. T. Kudryavtseva et al., IOP Conference Series Materials Science and Engineering 940, 01204 (2020) DOI: 10.1088/1757-899X/940/1/012046

14. S. Makhosheva, E. Vasilyeva, E3S Web of Conferences 244, 10027 (2021) DOI: https://doi.org/10.1051/e3sconf/202124410027

15. E. Vasilyeva, Y. Krupnov, E3S Web of Conferences 164, 10037 (2020) DOI: https://doi.org/10.1051/e3sconf/202016410037 
16. A. Mottaeva, MATEC Web Conf. 106, 08071 (2017) DOI: https://doi.org/10.1051/matecconf/201710608071

17. I.A. Sergeyev, Volga region region. Social sciences. Penza State University 1(33), 258267 (2015)

18. L.A. Kopteva, D.N. Kuznetsov, Customs readings - 2020. Development strategy 2030. Time calls. science and innovations: collection of materials of the International scientific practical conference (Saint Petersburg, Editorial and Publishing Department of the St. Petersburg branch of the Russian customs academy, 2020)

19. E. Markovskaya, A. Mottaeva, E3S Web of Conferences 258, 06066 (2021) https://doi.org/10.1051/e3sconf/202125806066 